\title{
がんゲノム医療における患者対応の経験から
}

\author{
四十物絵理子, * 井口亜橘, 持田かおり, 今井光穂, 林 秀幸, 西原広史
}

\section{Learning from My Experience: Outpatient Care for Cancer Multigene Genomic Testing}

\author{
Eriko Aimono, ${ }^{*}$ Aki Iguchi, Kaori Mochida, Mitsuho Imai, Hideyuki Hayashi, and Hiroshi Nishihara \\ Division of Clinical Cancer Genomics, Keio University School of Medicine; \\ 35 Shinanomachi, Shinjuku-ku, Tokyo 160-8582, Japan.
}

(Received August 28, 2019)

\begin{abstract}
We established an outpatient service in November 2017 to provide cancer gene profiling test services to cancer patients. To date, we have seen approximately 100 patients. Our staff includes genetic counselors and nurses specialized in genetic medicine. Our experience highlights the importance of healthcare professionals having in-depth knowledge of cancer therapeutic drugs and/or investigational drugs based on cancer genome medicine. Recently, poly (ADP-ribose) polymerase (PARP) inhibitors have been approved for treating breast cancer patients with germline $B R C A$ mutation; thus, in-depth knowledge of genetics and skills for genetic counseling are often considered indispensable in working with cancer patients. However, because the prompt treatment of clear and present cancer is the top priority in clinical settings, providing genetic information at that time, including that of unaffected family members, is of low priority for most patients who are dealing with the severe side effects of anti-cancer therapies. Pharmacists have an essential role to play in cancer therapeutics, talking with patients in order to assess their condition and to clarify the status of their treatment with anticancer agents. Genetic pharmacists should therefore work closely with genetics nurses and genetic counselors in the clinical practice of cancer genomic medicine. In this symposium, I would like to describe our experience caring for patients through our outpatient service, and to discuss the ideal framework for multidisciplinary cooperation to promote cancer genomic medicine.
\end{abstract}

Key words_ - genomic medicine; patient care; cancer multiple genomic testing

\section{1.はじめに}

慶應義塾大学病院は 2017 年 11 月にがん遺伝子外 来を開設し，遺伝子パネル検査を希望するがん患者 に対して 1 年間で約 100 名の患者対応を行ってき た.この外来には医師だけでなく専属の看護師・認 定遺伝カウンセラーが配置されているが，ここでの 患者対応の経験を通じて実感したことは「ゲノム医 療の現場では, 治療薬や治験薬に関する知識が最も 必要とされる」ということである。最近, poly (ADP-ribose) polymerase (PARP) 阻害薬オラパリ ブが「がん化学療法歴のある $B R C A$ 遺伝子変異陽 性かつ HER2 陰性の手術不能又は再発乳がん」に 承認されたこともあり，患者対応には遺伝に関する 知識やカウンセリング技術が必要不可欠と考えられ

慶應義塾大学医学部腫瘍センターゲノム医療ユニット ( ( 160-8582 東京都新宿区信濃町 35)

*e-mail: eriko0123@keio.jp

本総説は, 日本薬学会第 139 年会シンポジウムS49 で

発表した内容を中心に記述したものである.
ている，しかし，実際のがん遺伝子外来では既発症 者の治療が最優先事項であり，重い副作用に耐えな がらも必死で治療を続けている患者に対して，未発 症の家系員への情報収集は喫緊の課題とはならな い. 優先される聴取事項は過去の治療歴や副作用の 状況であり, 診察時に展開される話題も今後の治療 の可能性や新薬の作用機序に関することである.

こうしたがんゲノム医療の現場において，患者本 人の語りを傾聴し, 正しく状況を理解すべき職種と して, 看護師と並んで薬剂師が挙げられる。患者の 意思決定支援に携わっている自身の経験において も，薬剤に対する知識不足は否めず，ゲノム医療に 造詣の深い薬剂師の同席を切望する場面が少なくな い. 当シンポジウムでは, 当院のがん遺伝子外来で の患者対応の実例を紹介し，ゲノム医療における多 職種連携の目指すべき姿について議論したい.

\section{2. 実状}

当ユニットでは週 2 回がん遺伝子外来が開設され ており，自由診療としてがん遺伝子パネル検査 
「PleSSision 検査」について，がん既発症者を対象 に門戸が開かれ，検査の申し込みを受けている，看 護師や clinical research coordinator (CRC), 技師等 の当ユニットのがん遺伝子医療の教育を受けたス タッフが 1 時間程度事前説明を行い，申し込みやさ らに詳細な説明のため，ゲノム医療外来担当医師に つなぐ，二段階方式をとつている．患者はある程度 の知識をもって受診されるが，その理解度の幅は個 人間で大きく, また検査制度や仕組みが複雑であ り，まずは「がん遺伝子検査」の現段階の立ち位置 と, 当院で実地されてている, がん遺伝子検査につ いての説明を十分に行う必要がある。質問があれば 他施設で実施されている検査との違いを説明してい る. がん遺伝子検查で何がわかって，どのような有 用性があるのかということを正しく理解してもらう ことが，今後患者の治療方針の決定や医療従事者と してその患者とどのように接していくかという面 で, なにより重要となる. 具体的には, 現時点で, がん遺伝子検査は，がんの個性をより正確に捉える 検査である，ということを第一に伝える，そして， 検出され得る「個性」の中には，国内で使用可能な 薬剤が存在したり, 治験にエントリーできる種類の ものがあり，それらが，この検査によりみつかる可 能性があるということをお伝えする。しかし，われ われの行ってきた 400 例近くの自由診療におけるパ ネル検査の結果では, 検査の結果に基づいて薬剤を 使用できた患者さんは 1 割程度に留まっているとい う事実がある。理由として一番多いのは，検査結果 がわかるまでの時間，及び薬剤の入手に時間がかか り，治療開始時には残念ながら他界されていたり， 全身状態が悪化し治療が不可能となっていることな のである.

外来時に, 検査に関する話題の次に多いのが，今 までの治療歴についてである. 自由診療のがんパネ ル検査は高額であり，標準治療がすべて終わつたあ るいは終わる見込みで来院する患者さんが少なくな い，その場合に，今までの治療歴や副作用の話は絶 えることがない. 治療歴の確認や, 副作用の正しい 把握において薬剤師の関与が強く望まれる。 また, ゲノム検査後に新たな推奨薬剤が認められた場合, 治療の選択にこれまでの治療歴を考慮したり，薬剂 の入手においても問題は多数認められる. エキス パートパネルにおける推奨薬剤決定の際には，同様
に薬剤師の関与が大変重要であると考える。

\section{3. 遺伝性腫瘍症候群について}

がん遺伝子検查では，体細胞変異とともにコント ロールとして正常な白血球から胚細胞遺伝子も同時 に検索を行う。その場合に，発がんに係わる遺伝子 変異が, 生殖細胞系列バリアントとして認められる 可能性がある。事前説明時に患者さんに説明する重 要なポイントの 1 つであり, この検査により家族に 受け継がれる遺伝子の病的変異がみつかる可能性が あるということを本人及び同席している家族にしつ かり理解してもらう必要がある，その変異が，どれ ほどの発がんリスクがあり，そのリスクがわかるこ とで，患者及びその家族にどのような利益・不利益 が生まれてくるのかの判断は個別の事象において判 断が異なるため, 遺伝カウンセラーとともに詳細な リスク判断をして頂くフローになっている．事前説 明の段階では，そのような局面に遭遇する可能性が あるということを知ってもらう。また， BRCA 遺 伝子変異乳がんに対する PARP 阻害剤のように, 病的な生殖細胞系列バリアントを有する患者を対象 とした薬剤が保険診療内で認可され，ますますこう したケースへの対応が重要となってきている.

というのも，疾患名と使用薬剤の種類から，該当 患者の生殖細胞系列バリアントを認識できるからで ある。 今後そのような genome matched medicine に対応する薬剂は益々増えていくことは確実である が，患者自身がその意味を十分に理解していない可 能性があるので，その場合や治療開始時，開始前を 含め, やはり薬剤師からの説明及び，そのような薬 剂に対する取り扱いを，薬剂師がチームの中心とな り検討していく必要がある.

\section{4. まとめ}

がんゲノム医療の患者対応をしていく中で感じた 必要な医療と薬剂師の重要性について述べた。 そも そも，がんゲノム検査の検査所要時間が長いこと, 薬剂の選択基準が明確でないこと, 薬剤の入手に時 間がかかるなどの理由で，がんゲノム医療はまだま だ黎明期と言える。したがって，関与する医療者が それぞれの立場で患者さんに必要な情報を伝えてい く必要があり，その中でも薬剤師の関与は重要であ る.

利益相反＼cjkstart開示すべき利益相反はない. 